Volume 2 Nomor 2, September 2020, Halaman 107 - 117.

\title{
Pemenuhan Nutrisi dan Obat Alami Suku Dayak Losarang Melalui Pengolahan Infused Water
}

\author{
Anilia Ratnasari' ${ }^{1}$, Idah Hamidah ${ }^{2)}$, Nursubkhi ${ }^{3)}$ \\ ${ }^{1,2,3)}$ Program Studi Pendidikan Biologi Univeristas Wiralodra \\ Email: anilia@unwir.ac.id, $\underline{\text { idah.hamidah@unwir.ac.id, nursubkhi@unwir.ac.id }}$
}

\begin{abstract}
Abstrak
Infused water mulai dikenal dan dikonsumsi oleh sebagian masyarakat karea bahan bakunya alamiah, murah dan tidak merusak lingkungan. Berdasarkan hasil survey pada Suku dayak Losarang beberapa hal yang menjadi permasalahan, yaitu: 1). Kuatnya kepercayaan Ngaji Rasa yang menjadi aturan, 2). Pemahaman tentang kesehatan dari kebutuhan nutisi tubuh dan pengobatan alami masih sangat rendah, 3). Belum ada sosialisasi tentang pemenuhan kebutuhan nutrisi dan pengobatan dengan nilai-nilai alamiah, 4). Belum ada keterampilan dalam pengolahan infused water berbahan baku resep buah, sayur, dan rempah. Oleh sebab itu dilaksanakan kegiatan oleh tim pengabdian masyarakat sebagai solusi pemenuhuan nutisi dan obat alami Suku dayak Losarang melaui infused water bahan baku resep buah, sayur, dan rempah. Metode pelaksanaan kegiatan pengabdian kepada masyarakat adalah penyuluhan dengan metode sosialisasi dan diskusi, serta pelatihan pengolahan infused water berbahan baku resep buah, sayur, dan rempah. Berdasarkan hasil kegiatan pengabdian masyarakat adalah ; 1). Adanya kesadaran suku Losarang tentang pemenuhan nutrisi dan pengobatan sesuai dengan nilai-nilai alamiah, 2). Meningkatnya pengetahuan Suku dayak Losarang tehadap manfaat infused water berbahan baku resep buah, sayur, dan rempah, 3). Terciptanya keterampilan Suku dayak Losarang dalam pengolahan infused water berbahan baku resep buah, sayur, dan rempah sebagai pemenuhan nutrisi dan obat alami.
\end{abstract}

Kata Kunci;Suku dayak Losarang, Nutrisi,Obat alami, Infused Water

\begin{abstract}
Infused water is starting to be consumed because the raw material is natural. Based on the results of the survey on the Losarang Dayak tribe, several things became the problem, 1). The belief of the Ngaji Rasa that is the rule, 2). Understanding of the health of the body's nutritional needs and natural medicine is still very low, 3). There are no socialization about nutritional needs and treatment with natural values, 4). There are no skills in processing infused water made from fruit, vegetable, and spices. Therefore needs a solution to the fulfillment of nutrition and natural medicine for the Dayak Losarang. The method of implementing activities is counseling with the method of socialization and discussion, as well as training on the processing of infused water made from raw fruit, vegetable and spices. Based on the results of; 1). The awareness of the Losarang tribe about the fulfillment of nutrition and treatment in accordance with natural values, 2). Increased knowledge
\end{abstract}


of the Dayak Losarang Tribe the benefits of infused water made from fruit, vegetable and spices, 3). Skills of the Dayak Losarang tribe in processing infused water made from fruit, vegetable and spices as fulfillment of nutrition and natural medicine.

Keywords: Dayak Losarang tribe, nutrition, natural medicine, infused water

\section{A. Pendahuluan}

Suku Dayak Hindu Budha Bumi Segandu Indramayu (SDHBBSI) adalah sekelompok komunitas lokal yang mempercayai suatu ajaran bersama, Suku dayak Losarang menanamkan ajaran pada anggotanya supaya melaksanakan perbuatan yang benar dengan berbuat baik terhadap sesama manusia maupun lingkungan yang sangat mengagungkan nilai-nilai alamiah (Luzyawati \& Lissa, 2019). Berdasarkan hasil survey dan wawancara pada Suku dayak Losarang menganut ajaran kepercayaan dikenal dengan Ngaji Rasa yang diterapkan dalam kehidupan mereka sehari-hari, seperti makan dan minum secara alami sebagai contoh salah satu menu makan adalah rebusan daun kangkung ditambah nasi dengan dicuci tiga kali terlebih dahulu, dan tidak mengkonsumsi hewani. Dimasa pandemi ini pun suku dayak tidak mengikuti protokol sesuai anjuran pemerintah, karena memiliki kepercayaan bahwa Corona merupakan penyakit yang datang dari alam. Oleh karena itu diperlukan pemenuhan nutrisi sebagai upaya untuk menjaga kekebalan sistem imun tubuh.

Suku dayak Losarang juga tidak mengkonsumsi obat-obatan kimia untuk pengobatan berbagai penyakit, sebagian dari mereka ketika sakit hanya melakukan pengobatan dengan tidur saja sehingga memprihatinkan dalam penyembuhannya. Mereka mengenal ramuan sederhana dengan menggunakan 9 spesies jenis rempah dan 56 spesies jenis tumbuhan yang digunakan sebagai bahan makanan (Luzyawati \& Lissa, 2019), tetapi tidak semua anggotanya memiliki pengetahuan dan kesadaran akan bahaya penyakit. Meskipun banyak manfaat dari Infused water tetapi suku dayak Losarang belum mengetahui hal tersebut, maka terdapat beberapa hal yang menjadi permasalahan, yaitu: beberapa hal yang menjadi permasalahan, yaitu: 1). Kuatnya pengaruh ajaran kepercayaan Ngaji Rasa atau kembali ke alam yang menjadi aturan mereka dalam kehidupan sehari-hari seperti makan dan minum, 2). Pemahaman tentang kesehatan dari kebutuhan nutisi tubuh dan 
pengobatan alami masih sangat rendah, 3). Belum ada sosialisasi tentang alternatif pemenuhan kebutuhan nutrisi dan pengobatan dengan nilai-nilai alamiah, 4). Belum ada keterampilan dalam pengolahan infused water berbahan baku resep buah, sayur, dan rempah. Oleh karena itu dibutuhkan alternatif untuk meningkatkan kesehatan suku dayak Losarang dengan nilai-nilai alamiah sesuai ajaran mereka yaitu dengan obat-obatan alami melalui pengolahan infused water bahan baku resep buah, sayur, dan rempah.

Minuman infused water mulai dikenal dan dikonsumsi oleh sebagian masyarakat Indonesia karena proses pembuatannya sangat mudah tetapi harus memperhatikan kebersihannya (Surati\&Qoamriah,2017). Bahan bakunya alamiah murah dan sangat berlimpah serta tidak merusak lingkungan. Sebaiknya menggunakan buah, sayur lokal dan ditambah rempah-rempah. Buah yang biasa digunakan contohnya jeruk nipis, lemon, jeruk manis, strowberi, belimbing, nanas, kurma. Sayur yang dapat digunakan contohnya timun, sawi, seledri, daun mint. Dan rempah yang digunakan jahe, kunyit, kayu manis, sereh, kapu laga. Infused water adalah minuman air putih berisi potongan buah, sayur, rempah dan didiamkan beberapa jam sebelum diminum, sehingga air putih tersebut mempunyai kandungan dan rasa sesuai dengan buah/sayur/rempah yang di masukkan tersebut. Manfaat infused water dipercaya kaya akan sumber nutrisi seperti vitamin, mineral, dan juga memiliki antioksidan yang tinggi (Harifah, dkk. 2016) sehingga mampu memenuhi nutisi dan pengobatan secara alamiah sehingga menjaga kesehatan tubuh diantaranya; sebagai detoks alami, meningkatkan imunitas, dan melancarkan pencernaan (Harapan Rakyat, 2020).

Oleh sebab itu perlu diadakan kegiatan pengabdian masyarakat sebagai solusi pemenuhuan nutisi dan obat alami Suku dayak Losarang melaui pengolahan infused water bahan baku resep buah, sayur, dan rempah

\section{B. Metode}

Metode kegiatan pengabdian kepada masyarakat yang dilakukan sebagai solusi terhadap permasalahan yang muncul adalah meliputi; 1). Tahap perencanaan yaitu tim melakukan koordinasi awal perijinan dengan penjaga padepokan Suku Dayak Losarang, dan mempersiapkan alat, bahan sesuai dengan kebutuhan dalam 
pelaksanaan kegiatan pengabdian, 2). Tahapan pelaksanaan kegiatan pengabdian kepada masyarakat yang dilakukan adalah penyuluhan dengan metode sosialisasi, penyuluhan dan diskusi interaktif dengan Suku dayak Losarang tentang kesehatan, pemenuhuan nutrisi dan pengobatan secara alamiah melalui manfaat infused water, serta pelatihan praktik dalam teknik pengolahan pembuatan infused water berbahan baku resep buah, sayur, dan rempah pada bulan Oktober samai dengan November 2020, 3). Tahap analisis data secara kualtatif yaitu tim menganalisis pengetahuan dan ketrampilan Suku Dayak Losarang tentang infused water berbahan baku resep buah, sayur, dan rempah sebagai pemenuh nutrisi dan obat alami.

\section{Hasil dan Pembahasan}

Hasil kegiatan peyuluhan dan pelatihan tentang pemenuhan nutrisi dan obat secara alami dilaksanakan pada Suku Dayak Hindu Budha Bumi Segandu Indramayu (SDHBBSI) di Padepokan Desa Krimun Kecamatan Losarang, Kabupaten Indramayu, Jawa Barat, yaitu sebagai berikut; Kegiatan yang pertama penyuluhan dan sosialisasi diawali dengan penerimaan tim pengabdian oleh perwakilan suku dayak Losarang, kemudian acara dilanjutkan dengan penyuluhan dan sosialisai dengan metode ceramah tentang manfaat, kandungan dan bagimana pengolahan infused water yang berbahan baku resep buah, sayur dan rempah. Setelah penyuluhan ada sesi diskusi dengan pak warsidi sebagai juru bicara suku dayak Losarang. Beberapa resep Infused water disajikan pada gambar sebagi berikut;

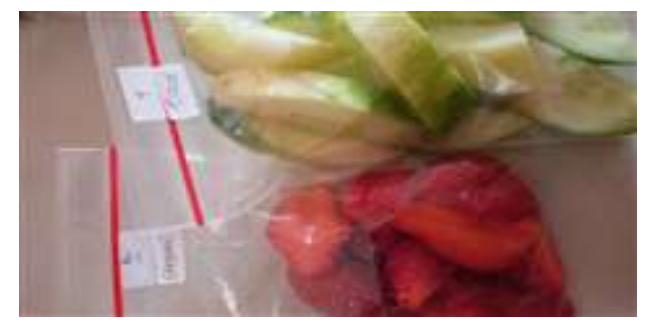

\section{Gambar.1. Stroberi dan Mentimun.}

Pada gambar 1. merupakan resep infused water dari bahan baku buah stroberi dan sayur mentimun. Kandungan buah stroberi memiliki kandungan vitamin $\mathrm{C}$ yang tinggi, asam folat, kalium, mangan, riboflavin, asam lemak, dan sebagai antioksidan. Sedangkan sayur mentimun berkahsiat mendetoksifikasi racun dalam tubuh, mengobati penyakit sariawan, hipertensi, jantung dan 
gangguan pencernaan, (Alina, 2019). Kandugan dan manfaat resep stroberi dan mentimun disampaikan pada saat penyuluhan infused water dengan Suku dayak Losarang.

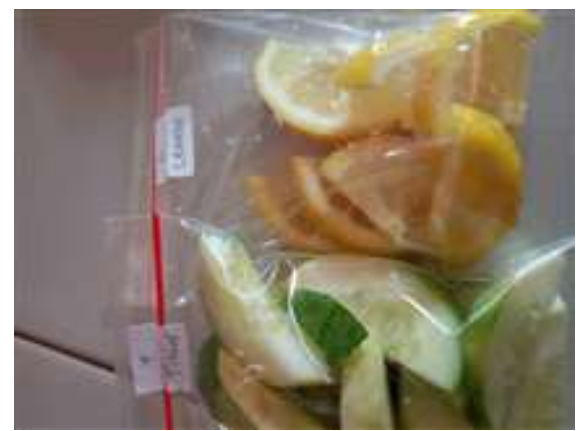

\section{Gambar.2. Lemon dan Mentimun.}

Pada gambar 2. merupakan resep infused water dari bahan baku buah lemon dan sayur mentimun. Lemon merupakan sumber vitamin $\mathrm{C}$ yang sangat tinggi dicampurkan dengan mentimun sebagai sumber serat. Resep ini sangat tepat dikonsumsi sebagai nutrisi tubuh. Kandungan dan maanfaat dari resep lemon dan mentimun disamaikan pada saat penyuluhan infused water dengan Suku dayak Losarang.
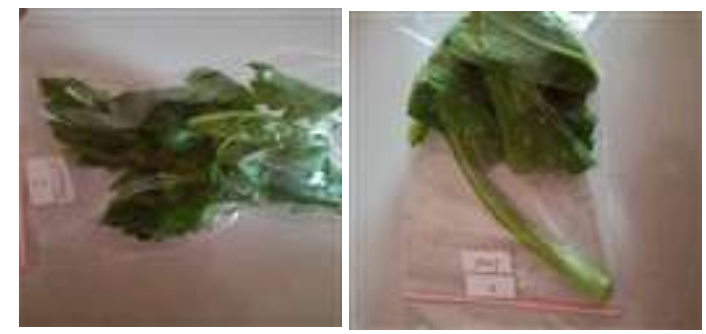

Gambar 3. Seledri dan Sawi

Pada gambar 3. merupakan resep infused water dari bahan baku sayur seledri dan sawi. Kandungan sawi sebagai serat alami dan juga mengandung vitamin, dan seledri pun memiliki banyak manfaat sebagai penurun hipertensi dan pembersih ginjal sangat baik untuk obat alami. Resep seledri dan sawi disampaikan pda penyuluhan infused water dengan Suku dayak Losarang.

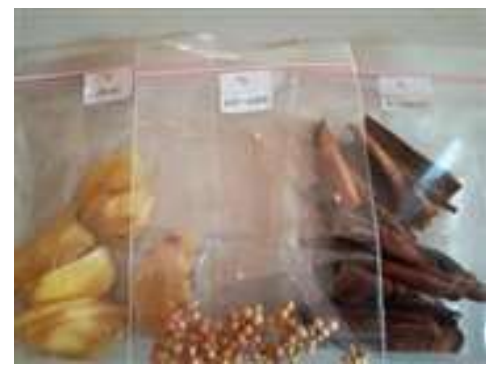

Gambar.4. Jahe, Ketumbar, dan Kayu Manis 
ABDI WIRALODRA

JURNAL PENGABDIAN KEPADA MASYARAKAT
ISSN 2656-5501 (Print)

ISSN 2714-8041 (Online)

Pada gambar 4. merupakan resep infused water dari bahan baku rempah jahe, ketumbar, dan kayu manis. Rempah-rempah ini sangat banyak manfaatnya sesuai dengan resep Zaidul Akbar, kombinasi jahe, ketumbar, kayu manis dan ditambahkan madu disampaikan pada kegiatan penyuluhan infused water dapat djadikan sebagai obat alami Suku dayak Losarang.

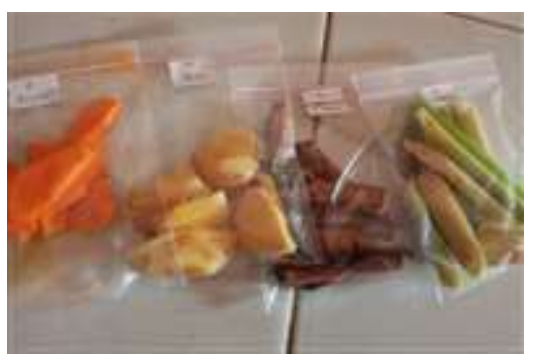

\section{Gambar. 5. Kunyit, Jahe, Kayu Manis, dan Sereh}

Pada gambar 5. merupakan resep infused water dari bahan baku rempah kunyit, jahe, sereh dan kayu manis. Kombinasi resep rempah ini sering disebut sebagai resep ultimate (Zaidul Akbar). Khasiat dari resep ini disampaikan pada kegiatan penyuluhan infused water sebagai detox alami tubuh dan suplemen daya tahan tubuh.

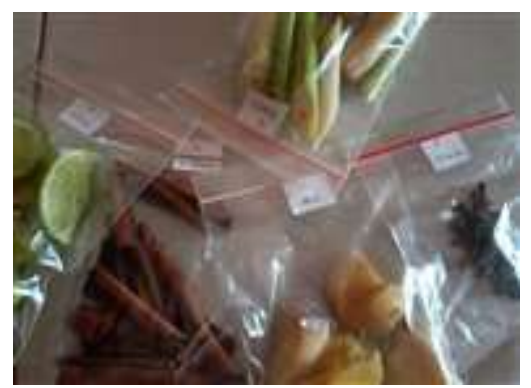

\section{Gambar.6. Jahe, Jeruk Nipis, Cengkeh, dan Kayu Manis}

Pada gambar 6. merupakan resep infused water dari bahan baku buah jeruk nipis, dan rempah jahe, sereh, kayu manis, juga cengkeh. Pada kegiatan penyuluhan infused water Suku dayak Losarang sangat tertarik dengan resep kombinasi anatara kandungan jahe, jeruk nipis, sereh, cengkeh, dan kayu manis, karena khasiatnya dapat digunakan sebagai obat alami untuk flu dan batuk. 


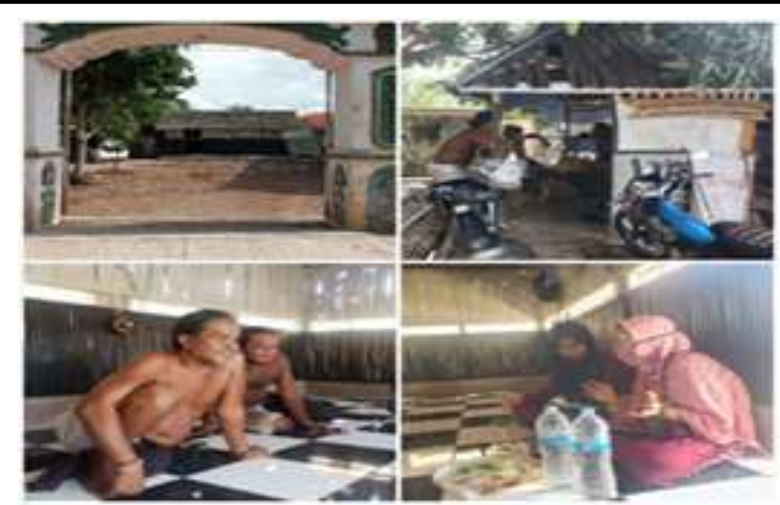

\section{Gambar.7. Kegiatan Penyuluhan Infused Water}

Pada gambar 7. merupakan pelaksanaan kegiatan sosialisasi, penyuluhan, dan diskusi interaktif tentang infused water berbahan baku buah, sayur, dan rempah untuk memenuhi kebutuhan nutrisi dan obat alami Suku dayak Losarang. Pada kegiatan penyuluhan ini Suku dayak Losarang sangat antusias sehingga dapat memberikan wawasan pengeathuan tentang resep infused water berbahan baku buah, sayur, dan rempah.

Hasil pelaksanaan pengabdian masyarakat yang kedua adalah kegiatan pelatihan teknik pengolahan infused water berbahan baku resep buah, sayur, dan rempah. Adapun prosedur pelatihan teknik pengolahan infused water sebagai berikut;

a. Menggunakan alat sederhana yang mudah didapat seperti botol jam atau botol plastik juga bisa ukuran yang digunakan 350ml, pisau, talenan, baskom, dan lain-lain.

b. Bahan yang digunakan untuk infused water dapat menggunakan resep berbahan baku seperti; buah stroberi, lemon, jeruk nipis, sayur mentimun, sawi, seledri, dan rempah yang digunakan yaitu kunyit, jahe, sereh, cengkeh, kayu manis, ketumbar, serta daun pandan.

c. Prosedur pembuatan infused water merujuk pada prosedur pembuatan infused water yang dilakukan oleh Murna, dkk, 2019 dengan inovasi dan modifikasi. Langkah-langkah pembuatan infused water menggunakan bahan baku resep buah, sayur, dan rempah dengan banyak dan berat sesuai selera yang dibutuhkan untuk setiap perlakuan. Kemudian bahan baku resep buah, sayur, dan rempah dimasukkan air mineral atau air putih matang yang telah diisi sebelumnya kedalam botol dengan volume 350ml. Selanjutnya 
ABDI WIRALODRA

JURNAL PENGABDIAN KEPADA MASYARAKAT
ISSN 2656-5501 (Print)

ISSN 2714-8041 (Online)

dilakukan penyimpanan sesuai perendaman selama 6 jam dengan ruang ataupun suhu lemari pendingin, sehingga setelah 6 jam kandungan nutrisi yang ada pada sayur, buah, dan rempah terlarut atau dikenal juga dengan air nano, sejalan dengan Zaidul akbar (https://youtu.be/wx0_vyuSi3U).

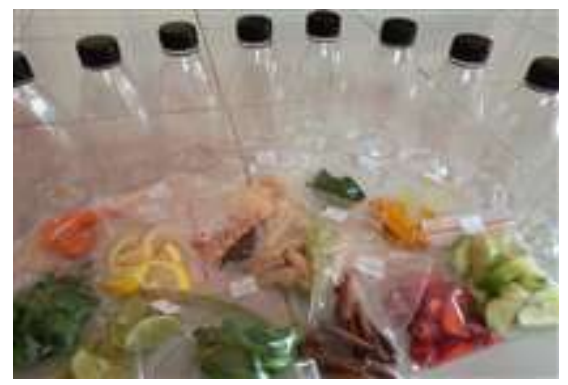

Gambar.8. Alat dan Bahan

Pada gambar 8. merupakan alat yang disiapkan oleh tim pengabdian dan bahan yang digunakan pada kegiatan pelatihan teknik pengolahan infused water berbahan baku buah, sayur, dan rempah dengan Suku dayak Losarang.

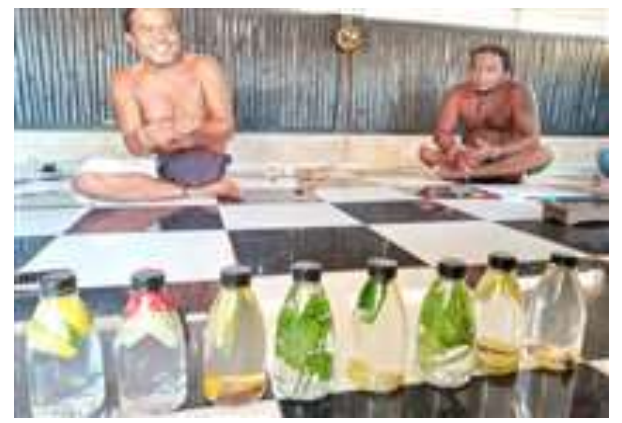

Gambar.9. Kegiatan Pelatihan Infused Water.

Pada gambar 9. Merupakan hasil dari kegiatan pelatihan teknik pegolahan infused water berbahan baku resep buah, sayur, dan rempah untuk memenuhi kebutuhan nutrisi dan obat alami, yang dilaksanakan leh tim pengabdian masyarakat dengan Suku dayak Losarang.

Tabel.1. Manfaat dan kesukaan Infused Water

Berbahan Baku Buah, Sayur, dan Rempah

\begin{tabular}{clc}
\hline $\begin{array}{c}\text { Bahan baku resep infused } \\
\text { water }\end{array}$ & \multicolumn{1}{c}{ Manfaat } & $\begin{array}{c}\text { Hasil } \\
\text { diskusi }\end{array}$ \\
& & \\
\hline Bauh stroberi dan timun & $\begin{array}{l}\text { Mem Menuhui kebutuhan } \\
\text { nutrisi miner }\end{array}$ & $\begin{array}{c}\text { Kurang } \\
\text { suka }\end{array}$ \\
& & \\
\hline
\end{tabular}




\begin{tabular}{|c|c|c|}
\hline \multicolumn{2}{|c|}{$\begin{array}{l}\text { ABDI WIRALODRA } \\
\text { JURNAL PENGABDIAN KEPADA MASYARAKAT }\end{array}$} & $\begin{array}{l}\text { ISSN 2656-5501 (Print) } \\
\text { ISSN 2714-8041 (Online) }\end{array}$ \\
\hline Buah lemon dan timun & $\begin{array}{l}\text { Memenuhi } \\
\text { nutrisi vebutuhan } \\
\text { vitamin } \quad \mathrm{C}\end{array}$ & Cukup suka \\
\hline Seledri & $\begin{array}{l}\text { Sebagai obat alami } \\
\text { pembersih ginjal }\end{array}$ & Cukup suka \\
\hline Sawi & Memenuhi kebutuhan & $\begin{array}{l}\text { Kurang } \\
\text { suka }\end{array}$ \\
\hline $\begin{array}{l}\text { Jahe, sereh, kayu manis, } \\
\text { cengkeh, dan }\end{array}$ & $\begin{array}{l}\text { Sebagai obat alami } \\
\text { batukdan flu }\end{array}$ & Suka \\
\hline Jeruk nipis & & \\
\hline $\begin{array}{l}\text { Jahe, kayu manis, } \\
\text { ketumbar }\end{array}$ & $\begin{array}{l}\text { Sebagai obat alami asam } \\
\text { lambung }\end{array}$ & Cukup suka \\
\hline $\begin{array}{l}\text { Kunyit, kayu manis, sereh, } \\
\text { jahe }\end{array}$ & $\begin{array}{l}\text { Sebagai oat alami detox } \\
\text { tubuh }\end{array}$ & Suka \\
\hline
\end{tabular}

Pada tabel 1. menjelaskan manfaat dari infused water berbahan baku resep buah,sayur, dan rempah, serta dari hasil dari diskusi interaktif yang menunjukkan bahwa Suku dayak Losarang memiliki kesukaan dan menerima infused water berbahan baku resep buah,sayur, dan rempah sebagai pemenuh nutrisi dan obat alami.

Bedarsarkan hasil penyuluhan dan sosialisasi kegiatan pengabdian infused water berbahan baku resep buah, sayur dan rempah, kemudian dilakukan sesi diskusi dengan Warsidi sebagai juru bicara Suku dayak Losarang, yang menyatakan bahwa infused water berbahan baku resep buah, sayur, dan rempah ini dapat diterima oleh Suku dayak karena sudah adanya pengetahuan tentang manfaat dan khasiat dari infused water. Hal ini sejalan dengan Alina. (2019) beberapa manfaat dari mengonsumsi infused water yaitu 1). Mengkonsumsi infused water dapat menambah nutisi seperti serat dan vitamin, 2). Infused water dapat menjadi alternative atau solusimengkonsumsi buah atau rempah menjadi minuman yang efisien, mudah, dan ekonomis. Adapn kandungan vitamin pada infused water buah-buahan seperti lemon dapat menurunkan kadar gula dalam darah, (Mohammad.,dkk, 2016). Khasiat dari buah atau rempah bisa didapatkan tanpa harus memakanya secara langsung. Nutrisi dari buah atau rempah akan keluar langsung kedalam air. Kandungan infused waterdapat memenuhi kebutuhan air terhindar dari dehidrasi dan dapat memenuhi kebutuhan nutrisi 


\section{ABDI WIRALODRA \\ ISSN 2656-5501 (Print) \\ JURNAL PENGABDIAN KEPADA MASYARAKAT \\ ISSN 2714-8041 (Online)}

tubuh juga dapat dijadikan obat serta detox alami (Oktariani, dkk.,2020). Warsidi juga memberikan saran untuk buah,sayur, dan rempah sebaiknya menanam sendiri. Hal ini sejalan dengan Teguh dan Karto, 2019 yang menyatakan budidaya tanaman sebagai penyediaan sumber pangan dan gizi.

Setelah kegiatan pelatihan teknik pengolahan infused water berbahan baku resep buah, sayur, dan rempah, sebagai juru bicara Suku dayak Losarang, menurut Warsid infused water ini sejalan dengan ajaran mereka yang sangat menjunjung tinggi nilai alamiah atau ajaran Ngaji Rasa. Hal ini dapat menjadi solusi Suku dayak Losarang yang memerlukan pemenuhan kebutuhan nutisi dan obat alami. Mereka sangat antusias mengikuti pelatihan pengolahan infused water berbahan baku resep buah, sayur dan rempah. Dan mulai tertarik untuk mencoba mengkonsumsi.

\section{Kesimpulan dan Saran}

Dari kegiatan yang telah dilakukan dapat disimpulkan bahwa kegiatan pengabdian kepada masyarakat berjalan lancar dan disambut antusias suku dayak losarang. Hal ini ditandai dengan adanya sambutan yang baik, ramah dan antusias dari pihak mitra. Selain itu, kegiatan ini merupakan menambah pengetahuan mitra yaitu suku dayak losarang tentang pengetahuan tentang bahan baku resep infused water dan keterampilan dalam pengolahan infused water sebagai solusi pemenuhan nutrisi dan obat alami untuk menjaga kesehatan apalagi dimasa pandemi ini. Saran perlu dilakukan sosialisasi yang lebih luas dengan berbagi mitra akan manfaat infused water. Didukug Surati dan Nurul, 2017 yang menyatakan Hasil pemeriksaan AngkaLempeng Total dan Most Probable Number Coliform semua sampel telah memenuhi syarat Standar Nasional Indonesia (SNI) maka minuman infused water layak untuk dikonsumsi.

\section{E. Daftar Pustaka}

Alina, U.S. (2019). Pengaruh Pemberian Infused Water Mentimun Terhadap Perubahan Tekanan Darah Pada Lansia Hipertensidi Wilayahkerja Puskesmas Takerankabupaten Magetan. Skripsi Program Studi Keperawatanstikes Bhakti Husada Mulia: Madiun.

Hamara, S. (2020). Manfaat Infused Water, Minuman Detoks yang Sedang Populer. Harapan Rakyat.com. 
Harifah, dkk. (2016). Aktivitas Antioksidan Infused Water Dengan Variasi Jenis Jeruk (Nipis, Lemon, Dan Baby) Dan Buah Tambahan (Stroberi, Anggur Hitam, Dan Kiwi). Jurnal Teknologi Dan Industri Pangan. 1(1).

Mohammad A.A, dkk.(2016). Effect Of Fruit-Infused Water (Combination Apple, Banana, and Lemon Of Blood Glucose In Young Man. Pakistan Journal Of Nutririon. 15 (7):,693-695.

Murna, M, dkk. (2019). Kajian Pembuatan Infused Waterdari Buah Kurma (Phoenix Dactylifera) Dengan Penambahan Jeruk Nipis (Citrus Aurantiifolia). Jurnal Teknologi Dan Industri Pertanian Indonesia. 11 (2),8489.

Luzyawati, L.,\& Lissa. (2019). Ethnobiology exploration of Suku Dayak Losarang, Indramayu District-West Java Province. Junal Bioscience 3.(2). https://doi.org/10.24036/0201932106093-0-00.

Oktarini, dkk. (2020). Edukasi Pemanfaatan Rempah Sebagai Bahan Dasar Pembuatan Infused Wateruntuk Detoksifikasi Tubuh. Jurnal Penelitian dan Pengabdian Kepada Masyarakat UNSIQ.7(3). 242-246.

Surati, S.,\& Qomariah, N.(2017). Tingkat Keamanan Minuman Infused Water Dengan Diversifikasi Penyimpanan Yang Berbeda. Jurnal Riset Kesehatan, $6(1), 13-19$.

Teguh, I. S., \& Karto. (2019). Pendampingan Budidaya Sayuran Sistem Hidroponik pada Kawasan Rumah Pangan Lestari (KRPL) Pengurus Cabang Bhayangkari Indramayu. Abdi Wiraldra Jurnal Pengabdian Masyarakat. 1(1),147-167.

https://kumpulan+resep+dr.+zaidul+akbar+pdf.Twitter @ zaidulakbar.

https://youtu.be/wx0_vyuSi3U.(2019). 